\title{
IMPROVING THE SMOKING PROCESS OF KITOZA, a traditional Malagasy meat PRODUCT
}

\author{
AmÉlioration de la CONDUITE DU FUMAGE DU KITOZA, \\ UN PRODUIT CARNÉ TRADITIONNEL MALGACHE
}

\section{REINGENIERÍA DEL AHUMADO DE KITOZA, UN PRODUCTO CÁRNICO TRADICIONAL MALGACHE}

\author{
A. Ratsimba ${ }^{1}$ D. Rakoto ${ }^{1}$ E. Arnaud ${ }^{2}$ T. Goli ${ }^{3}$ J. Ricci ${ }^{3}$ \\ V. Jeannoda ${ }^{1}$ D. Pallet ${ }^{3}$ M. Rivier ${ }^{3}$
}

\author{
Keywords: Smoked meat - Food quality - Madagascar. \\ Mots-clés : Viande fumée - Qualité des aliments - Madagascar. \\ Palabras clave: Carne ahumada - Calidad de los \\ alimentos - Madagascar.
}

\begin{abstract}
K itoza is a traditional Malagasy meat product made from beef or pork. It is presented as $20-50 \mathrm{~cm} \times 2-3 \mathrm{~cm}$ strips. Considered for a long time as a royal delicacy $(1,4)$, it still holds a special place in the daily meal of Malagasy people. Strips are salted, sun-dried and/or smoked either above the fire in the kitchen until consumption $(2,3)$ or in smoking units. Kitoza is no longer only prepared by housewives, it is also produced today commercially in modern facilities (butchers' shops and a few processing firms). Processing techniques of the product are not always controlled and frequently cause variations in quality. Meat smoking can lead to contamination by polycyclic aromatic hydrocarbons (PAH) which are carcinogenic compounds (6). Among them, benzo(a)pyrene (BaP) is a good indicator of carcinogenic compound contamination in cooked and smoked meat products.

This study aimed to improve the smoking process of kitoza in order to reach moisture and phenol contents close to the traditional product, while decreasing the PAH content by using charcoal and sawdust, since products smoked with these fuels show acceptable PAH levels (below European norms) (5). The unit operations of drying/cooking and smoking were also separated to ensure sufficient smoking and conduct drying/cooking in a configuration which might not generate $\mathrm{PAH}$.
\end{abstract}

The raw material used was pork ham cut into strips that were then salted at $10 \mathrm{~g} / \mathrm{kg}$ of meat. Kinetics of water loss, phenols and $\mathrm{BaP}$ gain during smoking assays with only wood, and assays alternating cooking/drying with charcoal and smoking with sawdust phases were assessed. The different treatments consisted in: (i) cooking/drying with charcoal (4 h) and smoking with sawdust (2 h), (ii) smoking with sawdust (2 h) and cooking/drying with charcoal (4 h), and (iii) cooking/drying/smoking with small bricks of wood (6 h). Each treatment was repeated three times.

\footnotetext{
1. Département de biochimie fondamentale et appliquée, Université d'Antananarivo, Antananarivo, Madagascar.

2. Cirad, UMR QualiSud, station de Ligne-Paradis, 7 chemin de l'IRAT, 97410 Saint-Pierre, Réunion, France.

3. Cirad, UMR QualiSud, TAB-95/16, 73 rue Jean-François Breton,

34398 Montpellier Cedex 5, France.
}

Figure 1 shows the evolution of the air temperature in contact with the meat during smoking. We tried to stabilize the smoking unit temperature at about $100^{\circ} \mathrm{C}$, since it was the average temperature in the traditional smoking process. The temperature in the traditional process seemed $10-20^{\circ} \mathrm{C}$ below those of the experimental treatments (Figure 2). However, Figure 3 shows that water contents $(55 \%)$ were not significantly different in experimental Kitoza compared to the traditional one. After 6 hours of heat treatment, the moisture content was between 40 and 50\%.

Kinetics of total phenol accumulation on meat strips (expressed on a dry basis) are shown in Figure 4. The traditional process reached about $5 \mathrm{mg} / 100 \mathrm{~g}$ total phenols at end point. The charcoal-sawdust treatment induced a slight and linear increase in phenols as soon as sawdust was added (i.e. after 4 hours of charcoal cooking/ drying). Phenol content reached about $4 \mathrm{mg} / 100 \mathrm{~g}$ after 2 hours of smoking, a value close to that of the traditionally-processed product. Phenol contents obtained with sawdust-charcoal and wood treatments reached higher levels (about $10 \mathrm{mg} / 100 \mathrm{~g}$ ) than that of the traditional one $(5 \mathrm{mg} / 100 \mathrm{~g})$. The sawdust-charcoal treatment provoked very fast and efficient phenol deposit in the beginning, comparable to that of wood alone. It could be explained by the high moisture content of the surface layers of the meat strips in the first period of the process. The phenol content peaked after about one hour of exposure to sawdust smoke. The phenol content remained then unchanged until the end of the process. Since

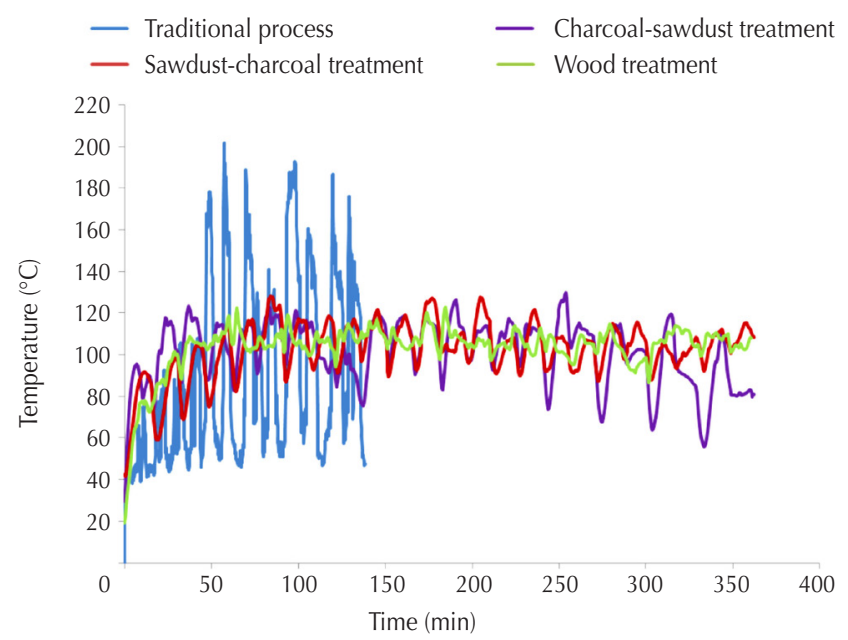

Figure 1: Air temperature evolution during smoking of pork kitoza using different processes in Madagascar (3 replicates). 


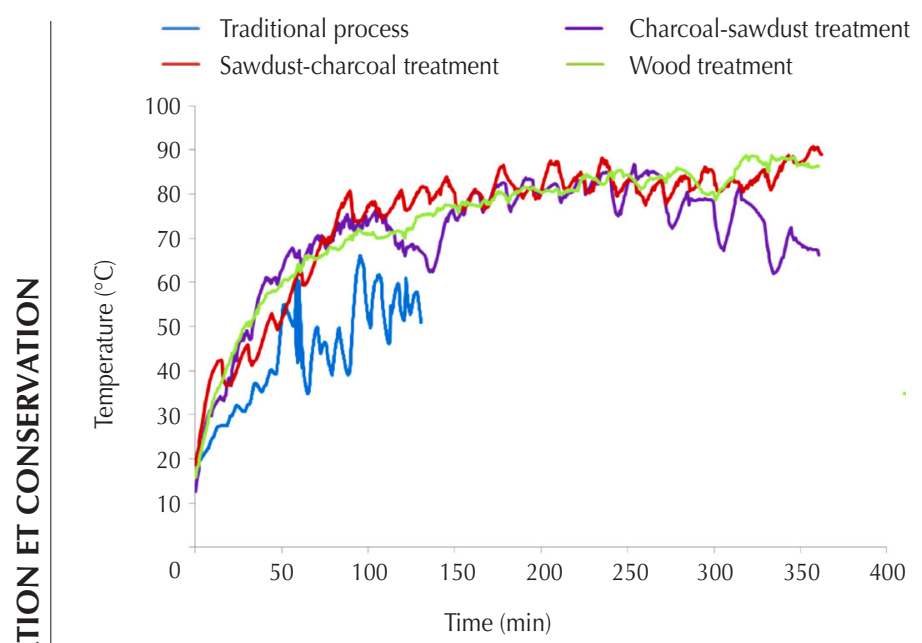

Figure 2: Core temperature evolution during smoking of pork kitoza using different processes in Madagascar (3 replicates).

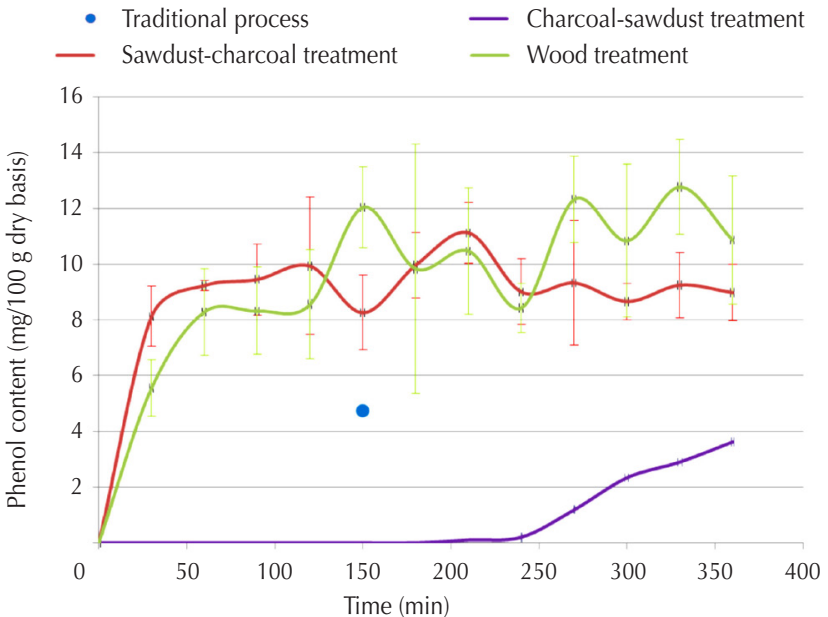

Figure 4: Phenol content (dry basis) kinetics during smoking of pork kitoza using different processes in Madagascar (3 replicates).

this parameter was expressed on a dry basis, it would mean that the deposited phenols remained in the meat strips and were not destroyed neither did they evaporate. Figure 5 shows the kinetics of BaP accumulation on strips on a wet basis. Regardless of the duration of charcoal-sawdust or sawdust-charcoal treatments, BaP contents were lower than $2 \mu \mathrm{g} / \mathrm{kg}$. For these two treatments, a slight increase was recorded after 3 hours in relation with the concentration effect due to water evaporation. In the wood treatment, accumulation was linear and $\mathrm{BaP}$ reached very high levels: $20 \mathrm{ppb}$ after 2.5 hours and 40 ppb after 6 hours. In the traditional process, 8 ppb were reached after 2.5 hours. In the latter two cases, this could be related to wood pyrolysis at high temperature in a system allowing direct exposure to fire.

Processes without wood are very promising to reduce PAH accumulation during drying and smoking. Compared with the traditional process, splitting operations between cooking/drying with charcoal on one hand, and smoking with sawdust on the other hand allowed the same decrease in water content, effective phenol deposit which could be modulated according to the desired result, and decrease in PAH content in compliance with new European Union regulations. Reengineered products will be subjected to sensory and consumer acceptance analyses with Malagasy consumers, and the duration of preservation will also be assessed.

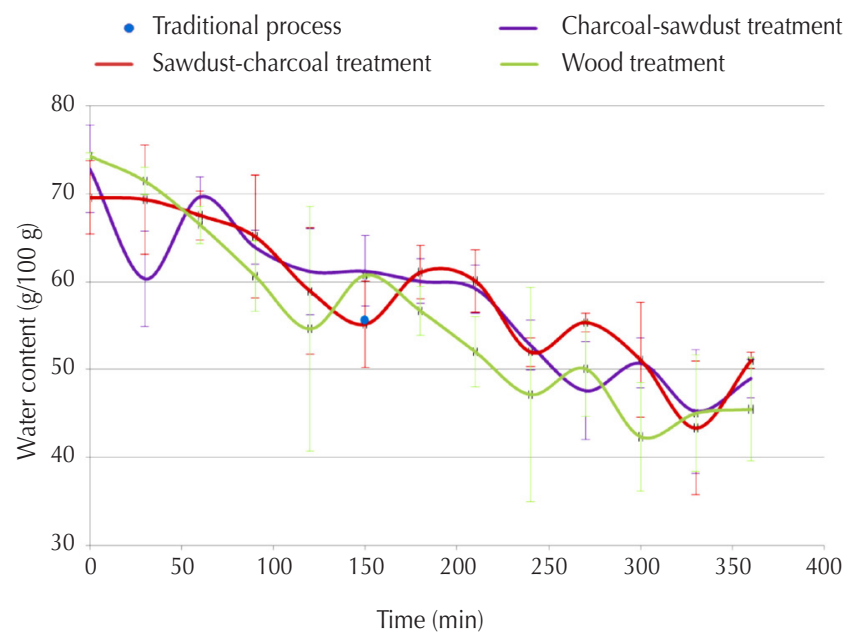

Figure 3: Moisture content (wet basis) kinetics during smoking of pork kitoza using different processes in Madagascar (3 replicates).

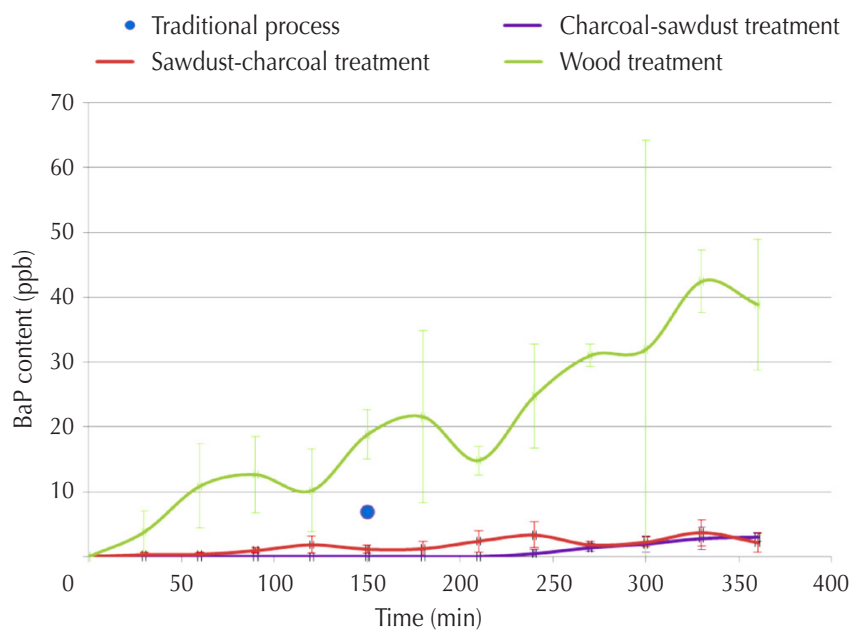

Figure 5: Benzo(a)pyrene (BaP) content (wet basis) kinetics during smoking of pork kitoza using different processes in Madagascar (3 replicates).

\section{Acknowledgments}

Studies on kitoza were funded by the European Union through the project African Food Tradition rEvisited by Research. Reengineering experiences were also funded by the CAP EXPORT Project of the Chambre de Commerce et $d^{\prime}$ Industrie, France, Madagascar.

\section{REFERENCES}

1. CALLET R.P., 1902. Tantaran'Andriana. Bull. Acad. Malgache, $3: 166$.

2. LAURENT C., 1981. Conservation des produits d'origine animale en pays chauds. Paris, France, ACCT, p. 157.

3. MOLET L., 1978. Le feu domestique et la cuisine chez les Mérina (Madagascar). Bull. ASEMI, 9 : 49-66.

4. MONDAIN G., CHAPUS G.S., 1948. Historique du bœuf d'après les Tantaran'Andriana. Bull. Acad. Malgache, $7:$ 191-223.

5. NAKAJIMA D., NAGAME S., 2007. Polycyclic aromatic hydrocarbon generation behavior in the process of carbonization of wood. Bull. Environ. Contam. Toxicol., 79: 221-225.

6. PURCARO G., MORET S., CONTE L.S., 2013. Overview on polycyclic aromatic hydrocarbons: Occurrence, legislation and innovative determination in foods. Talanta, 105: 292-305.

Accepted 30 April 2015; Online publication June 2015 